
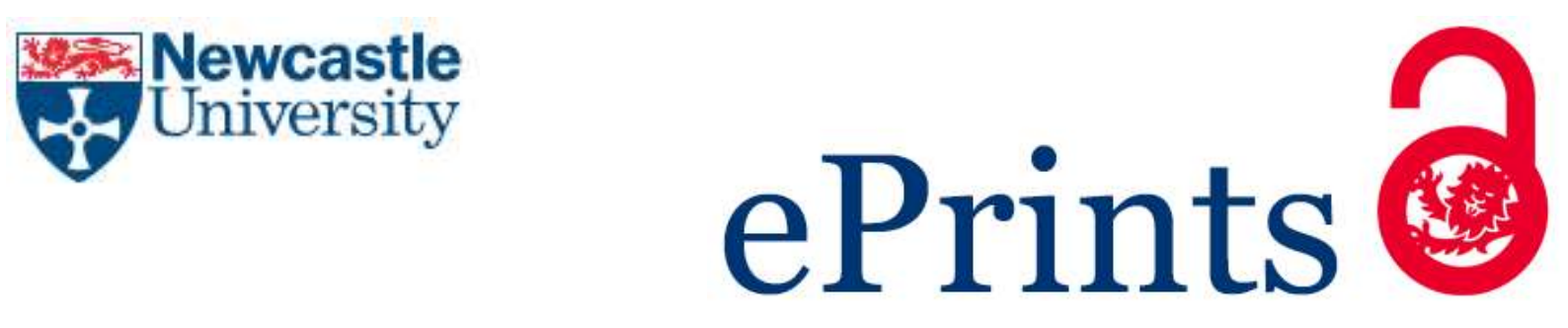

Satar HM, Wigham CR. Multimodal instruction-giving practices in webconferencing-supported language teaching. System 2017, 70, 63-80.

\title{
Copyright:
}

(C) 2017. This manuscript version is made available under the CC-BY-NC-ND 4.0 license

DOI link to article:

https://doi.org/10.1016/i.system.2017.09.002

Date deposited:

03/10/2017

Embargo release date:

29 September 2019

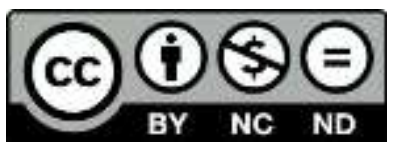

This work is licensed under a

Creative Commons Attribution-NonCommercial-NoDerivatives 4.0 International licence 
This is the author version of the following paper published in System:

H. Müge Satar, Ciara R. Wigham, Multimodal instruction-giving practices in webconferencing-supported language teaching, System, Volume 70, November 2017, Pages 63-80, ISSN 0346-251X, https://doi.org/10.1016/j.system.2017.09.002.

\section{Multimodal instruction-giving practices in webconferencing-supported language teaching}

\section{Abstract}

This paper focuses on instruction-giving practices, a crucial but under-researched aspect of online language tutorials. The context for this qualitative study is a telecollaborative exchange focussing on French as a foreign language. We investigate trainee teachers' instructions for a role-play rehearsal task during webconferencing-supported language teaching sessions.

Multimodal (inter)action analysis (Jewitt, Bezemer, \& O’Halloran, 2016; Norris, 2004) of the data from three sessions reveals how the trainees mark different stages in the instructions using gaze and webcam proximity, allocate roles helped by the use of gaze (Satar, 2013) and gestures (Guichon \& Wigham, 2016; McNeill, 1992), and introduce key vocabulary using wordstress, gaze and text chat strategies. The paper sheds light on the need to demonstrate clear boundaries between instructions and beginning of the task and the need, in future online teacher training programmes, to prepare trainees to direct learners' attention to the resources needed for task accomplishment, explain how the task will be accomplished using the online resources and harness the potential of semiotic resources during this teaching phase.

Keywords: teacher training; instruction-giving; multimodality; multimodal (inter)action analysis; videoconferencing; task-based language teaching

\section{Task-based language teaching and instruction-giving}

In Second Language Acquisition, task is considered an important component of the language classroom as it offers opportunities for authentic, meaning-focused interaction (Ellis, 2003; Nunan, 2004). Task-Based Language Teaching (TBLT) research distinguishes between 
two approaches to task accomplishment: task-as-workplan, i.e. what is designed, and task-asprocess, i.e. the actual performance that takes place when accomplishing the task (Breen, 1987).

Several typologies identify various task types (e.g. Pica, Kanagy \& Falodun, 1993). Nunan (2004) classifies pedagogical tasks on a continuum from activation to rehearsal tasks. Activation tasks offer learners opportunities to activate their emerging language skills in creative ways, whilst rehearsal tasks require learners to practise some out-of-class performance. As such, a rehearsal task "bears a clear and obvious relationship to its corresponding real-world counterpart" (Nunan, 2004:20) and may take the form of role-play. Yen, Hou and En Chang (2015) argue for the use of role-play as "an important strategy in that it focuses on the ability to speak and communicate by playing different roles in a given real-world situation" (p.386) helping to improve learners' writing and speaking skills.

The role of the teacher in guiding and facilitating learning during task completion also merits attention. Van den Branden (2006) assigns two roles to teachers in TBLT: motivating the learners and interactionally supporting task performance by ensuring that rich input is comprehensible, by triggering negotiation for meaning sequences and by supporting output and focus on form. Raith and Hegelheimer (2010) further describe a model for task-based teaching competencies for teachers in task introduction, performance and evaluation stages. They identify three competencies for the task introduction stage:

A1 Can pose tasks in such a way that students can set goals for themselves and actively participate during the task.

A2 Can introduce the task in such a way that task demand and task support are balanced and that students actively participate during the task. 
A3 Can explain tasks so that the purpose, expected result and the steps towards task completion are clear and understandable for the students (p.162).

Following Raith and Hegelheimer's (2010) teacher competencies, instruction-giving sequences are relevant at this task introduction stage of teaching competencies. Watson Todd (1997:32) describes instructions as "a series of directives, possibly mixed with explanations, questions and so on, which as a whole aim to get the students to do something". In their 2008 paper, Watson Todd, Chaiyasuk and Tantisawetrat argue for the significance of instruction-giving sequences, stating that "the success of the activities which follow instructions is often predicated on the effectiveness of these instructions" (p.26). They underline that instructions are an important part of the language classroom as an occasion in which language is used for real communication. However, there is limited research to date that investigates instruction-giving practices in TBLT.

One of the few studies that explores instruction-giving practices in TBLT was conducted by Seedhouse (2008). He studied classroom interaction within a conversation analysis (CA) approach and his analysis of instruction-giving practices illustrates how experienced teachers and trainee teachers create, manage and maintain a shift in focus. He concludes that experienced teachers' instructions "tend to be simple, clear and focused" (p.53). Seedhouse argues for the presentation of a full, explicit and single focus, and summarises the different ways in which teachers established and managed focus as follows:

Shifts in focus seem to be distinctly marked in the data in some way by successful experienced teachers. They may be marked by use of discourse markers, by prosodic features, by changes in the spatial configuration of the participants, by meta-discoursal comments which indicate that a shift is occurring and by semiotic means (pp.48-49). 
Other studies have emphasised the role of the semiotic resources in classroom interaction. Hellermann \& Pekarek Doehler (2010) show how learners' employ posture shifts as “an important signal characterising classroom task starts" (p.30) and how mutual posture alignment functions as a signal to launch the task without further verbal meaning negotiation. Moreover, Kääntä (2015) demonstrates "how teachers employ gaze, pointing gestures, and head nods to nominate next speakers (i.e. give response turns to students)" (p.65).

Markee (2015a) is the only study to date that aims to specifically study teachers' instruction-giving practices in task-based instruction. His investigation follows an ethnomethodological perspective and he concludes that "non-verbal aspects of communication are a vital part of instructions" (p.126). Markee (2015a) evidences how participants orient to cultural artifacts, employ gaze, gestures and embodied actions in order to "collaboratively converge on courses of action" (p.127). Moreover, he identifies six fragments included in instruction-giving sequences informing learners:

(1) how they will be working (in dyads or small groups),

(2) what resources they will need,

(3) what tasks they have to accomplish,

(4) how they will accomplish the task,

(5) how much time they have to accomplish these tasks,

(6) why they should do something (pp.120-121).

In a further study, Markee (2015b) highlights the lack of research on instruction-giving sequences, especially in second language studies and stresses the need for further research as "we still know little about how instruction giving sequences in language classrooms are set in motion" (p.3). 
The studies cited above on instruction-giving in language learning classrooms relate to face-to-face classrooms predominantly using a CA methodology focusing on the moment-bymoment construction of interaction ${ }^{1}$. Although several studies have examined the use of multimodal resources in webconferencing-supported teaching (Codreanu \& Combe-Celik, 2013; Develotte, Guichon, \& Vincent, 2010; Hampel \& Stickler, 2012; Örnberg Berglund, 2009; Satar, 2013; Guichon \& Wigham, 2016), we failed to identify any studies specifically dedicated to instruction-giving sequences. For instance, although talk-external artefacts can also play an essential role in the accomplishment of online tasks, their employment must be appropriated by teachers and learners due to restricted access to visual cues signalling learner orientation to the artefact, including gaze and posture. Furthermore, the artefacts themselves are frequently disembodied/non-physical, electronic resources, e.g. online pictures and videos, text chat, external websites. Therefore, individual orientation to the resources and visual elements are difficult to discern. In the absence of posture alignment in online settings, semiotic resources that signal teachers' orientation towards teaching resources could perhaps become visible by paying particular attention to slight changes in their gaze or proximity to the screen. For instance, regularities could be observed in the direction of the teacher's gaze or closeness to the camera when performing certain pedagogical actions, such as giving instructions, monitoring learner interaction or providing feedback using text chat.

Given limited embodiment available in online communication, even when it involves video interaction, pedagogical competence for giving task instructions would perhaps need to be

\footnotetext{
${ }^{1}$ Given the fact that few studies we found on instruction-giving practices followed CA, our literature review does in a way frame our study within the ethnomethodological/CA analysis. However, our interest is not particularly on the moment-by-moment construction of the instruction-giving sequences, but only on the salient moments in the instructions in which semiotic resources are employed. Therefore, we used multimodal (inter)action analysis following Norris (2004, 2016), Jewitt (2011) and Jewitt, Bezemer \& O’Halloran (2016) as explained under section 2.3 Theoretical framework for data analysis.
} 
supported by a multimodal competence of managing online instruction-giving sequences. Thus, this paper aims to analyse how trainee teachers give task instructions in webconferencing for a role-play rehearsal task and employ semiotic resources in their instruction-giving practices. More specifically, in an attempt to address and provide for trainee language teachers' needs in future teacher training programmes, the following question and secondary set of questions are addressed:

How do trainee language teachers employ semiotic resources ${ }^{2}$ when giving instructions for a role-play task in online language tutorials?

1. How do trainee language teachers signal the beginning and different fragments of instructions using semiotic resources?

2. How do trainee language teachers allocate the roles required by the task using semiotic resources?

3. How do trainee language teachers deal with key vocabulary items in the instructions using semiotic resources?

\section{Methods}

\subsection{Context}

This study draws on data from the ISMAEL corpus (Guichon et al., 2014) that structured interactions from a telecollaboration project that brought together 18 undergraduate Business students in their third semester of learning French at Dublin City University, Ireland, and 12 trainee teachers on a Master's programme in Teaching French as a Foreign Language at Université Lyon 2, France. For the Master's students, the exchange formed part of an optional module in online teaching that aims to help them develop professional skills to teach French

\footnotetext{
2 "Semiotic resources are the actions, materials and artifacts we use for communicative purposes, whether produced physiologically - for example, with our vocal apparatus, the muscles we use to make facial expressions and gestures - or technologically - for example, with pen and ink, or computer hardware and software - together with the ways in which these resources can be organized." (van Leeuwen, 2004:285)
} 
online and develop reflective analysis around their teaching practices. For the undergraduates, the exchange composed part of a 12-week Business French module of CEFR level B1.2 (Council of Europe, 2001). Module outcomes included understanding spoken French on topics related to professions, work placements and job applications.

The telecollaboration project ran for six weeks in autumn 2013. Participants met for weekly 40-minute sessions in the webconferencing platform Visu (Guichon, Bétrancourt \& Prié, 2012). Following an introductory session, each online session was designed by two of the trainees and was thematic. The online interactions were part of a larger circular learning design (detailed in Guichon \& Wigham, 2016).

The Visu platform was chosen for the webconferencing interactions because it was specifically designed for synchronous language teaching-learning. Interactions were influenced by the functionalities that are specific to the tool (see Table 1 and Figure 1). Participants connected to Visu from university language labs. Because of uneven numbers, most trainees worked with two learners whilst two trainees had one-to-one sessions.

Table 1: Functionalities of Visu

\begin{tabular}{|l|l|}
\hline Audio & Full duplex. \\
\hline Text chat & No private channels available. \\
\hline $\begin{array}{l}\text { Video images (via } \\
\text { webcam) }\end{array}$ & $\begin{array}{l}\text { Large pictures of learners, small image of the trainee } \\
\text { (trainee's perspective). } \\
\text { Large image of trainee and other learner, small image of self } \\
\text { (learner's perspective). }\end{array}$ \\
\hline Markers & $\begin{array}{l}\text { Personal notes that trainees can place on the session timeline } \\
\text { during the synchronous interaction. }\end{array}$ \\
\hline $\begin{array}{l}\text { Multimedia } \\
\text { activity resources }\end{array}$ & $\begin{array}{l}\text { Section on the interface where trainees can collate the } \\
\text { materials they will need for the synchronous session, e.g. pre- } \\
\text { prepared notes, images, videos, hypermedia links. }\end{array}$ \\
\hline Automatic & \begin{tabular}{l} 
This is a technical function included in the Visu platform. \\
\hline
\end{tabular}
\end{tabular}




\begin{tabular}{|l|l|}
\hline recording & $\begin{array}{l}\text { Interactions are automatically recorded when a session is } \\
\text { opened, allowing for re-viewing of sessions for training } \\
\text { purposes. }\end{array}$ \\
\hline
\end{tabular}

Figure 1: Visual screen layout of Visu (trainee's perspective) as per 2013.

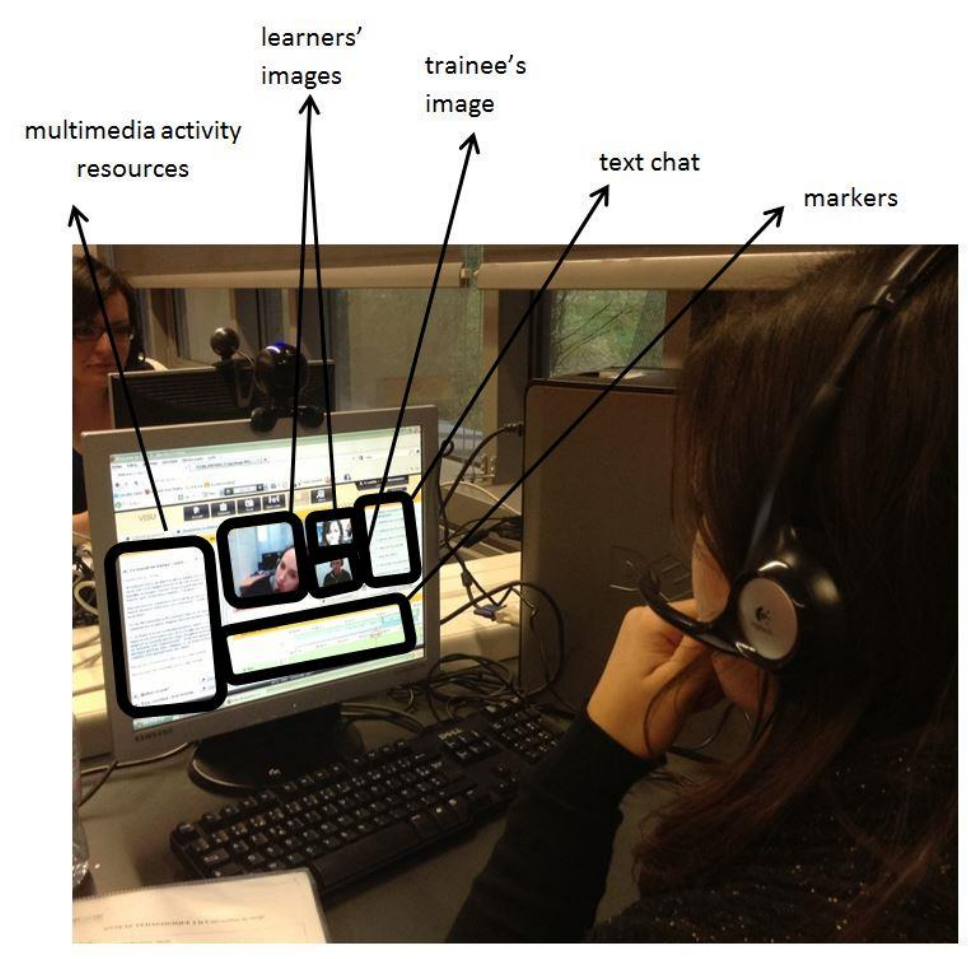

\subsection{Selection of interaction data and participants}

This paper analyses data obtained from the recordings of the fourth session. The rationale for selecting this session was that the participants already had some experience of teaching online and had established social relationships. Moreover, the opportunities the task in this session, i.e. role-play, may afford to answer our research questions were also considered. The role-play task required inclusion of many fragments for task instructions, including role designation, making a list and explanation of the context for the roles. Furthermore, the role-play task was structured, which made it easier to identify the segment in the sessions allocated for the task and the instruction-giving sequences for analysis. Other tasks, for example job applications and 
interviews, were less structured involving discussions and opinion-exchange and were more conversational, and identification of the relevant segments for analysis was not straightforward.

The role-play task concerned project management. This rehearsal task included three components. First, learners were asked to imagine that they worked at a fast-food outlet and the trainee would be the manager. They had to reflect upon a new formula for organising children's birthday parties at the outlet. The lesson plan suggested trainees check whether fast-food companies in Ireland ran birthday parties as is the custom in France. Secondly, the learners needed to create, in the text chat, a list of the necessary actions to put the new formula into place. This instruction explicitly stated that trainees should limit their contributions in the activity allowing the learners to use the text chat and complete each other's contributions. Finally, the trainee, i.e. the manager, should lead a reflection on the list compiled. The lesson plan offered sample prompt questions.

A sub-corpus from three of the seven teacher trainees, each of whom was working with two learners, was chosen for analysis. ${ }^{3}$ Ethical approval and informed consent were obtained prior to data collection. Pseudonyms are used for all personal information (see Table 2). When requested, images are blurred to ensure anonymity of the participants.

Table 2. Participants' pseudonyms, gender and session lengths

\begin{tabular}{|l|l|l|l|}
\hline Teacher trainee & Learner 1 & Learner 2 & Length of session \\
\hline Samia $(\mathrm{F})$ & Sean $(\mathrm{M})$ & Angela $(\mathrm{F})$ & 35 mins. \\
\hline Etienne $(\mathrm{M})$ & Conor $(\mathrm{M})$ & Sophie $(\mathrm{F})$ & 20 mins. \\
\hline
\end{tabular}

\footnotetext{
${ }^{3}$ In the global ISMAEL corpus, two trainees conducted sessions with only one learner and five trainees worked in triads with two learners. Working with one learner changed the requirements for the role-play task. Therefore, this data was excluded in the sub-corpus for analysis. The recording for one of the other triads was not good enough to be included in the analysis. Analysis of instruction-giving sequences of the final triad revealed that all relevant features were already represented by other cases, and analysis is therefore not included in this paper due to word constraints.
} 


\begin{tabular}{|l|l|l|l|}
\hline Mélissa (F) & Ana (F) & Alejandra (F) & 30 mins. \\
\hline
\end{tabular}

\subsection{Theoretical framework for data analysis}

This study employs multimodal (inter)action analysis (Norris, 2004; Jewitt, 2011) in order to explore instruction-giving practices of trainee teachers. According to Norris (2004) multimodal (inter)action analysis aims to "understand and describe what is going on in a given interaction" (p.4). Multimodal (inter)action analysis "expands the focus of interaction ... to explore how people employ gesture, gaze, posture, movement, space and objects to mediate interaction in a given context" (Jewitt, 2011: 34) and "the work of the actor is seen as central" (Jewitt, Bezemer, \& O'Halloran, 2016: 114). The parentheses around 'inter' "highlight that all actions, no matter if they are taken with another human being, or objects within the setting, or the environment, are interactions" (Norris \& Pirini, 2016: 24). Therefore, the term 'interaction' is used in its wider sense including interaction between an actor and his/her environment and among different modes that are employed.

Multimodal (inter)action analysis draws on concepts from a variety of theoretical approaches, including mediated discourse, social interaction studies and social semiotics, and it allows the researcher to deploy numerous methodological tools to move between macro, intermediate and micro analysis (Jewitt, Bezemer, \& O'Halloran, 2016; Norris \& Pirini, 2016) in order to describe a range of communication modes and the "situated interplay between modes at a given moment in social interaction" (Jewitt, Bezemer, \& O'Halloran, 2016: 115).

In employing a multimodal (inter)action analysis, we engage with the contributions of gestures, gaze and proxemics in the visual mode. Communicative gestures are the movements of the hands and arms produced with the intention of serving a role in the communicative exchange. They are a set of semiotic resources that draw on temporal and spatial resources and their use is socially and culturally regulated. We draw upon McNeill's (1992) schema to categorise 
communicative gestures as iconic, metaphoric, deictic or beats, to which we add the category of emblems (Kendon, 1982) referring to culturally specific gestures (Table 3).

Table 3: Gesture categorisation

\begin{tabular}{|l|l|}
\hline Iconic & $\begin{array}{l}\text { Possess a pictorial content, often mimicking what is } \\
\text { conveyed verbally, describing specific objects or events. }\end{array}$ \\
\hline Metaphoric & Visual representations of abstract ideas and concepts. \\
\hline Diectic & $\begin{array}{l}\text { Pointing gestures that refer to real/abstract objects, } \\
\text { people, places or directions. }\end{array}$ \\
\hline Beat & Quick movements coherent with rhythm. \\
\hline Emblems & $\begin{array}{l}\text { Culturally conventionalized gestures with defined } \\
\text { meanings that often replace verbal communication. They } \\
\text { have standard forms and significances. }\end{array}$ \\
\hline
\end{tabular}

Gaze is considered as "the direction of orientation that people display through the positioning of their head, notably their eyes, in relation to their environment" (MODE, 2012). In face-to-face settings, gaze can be a multimodal resource in organising the activity by regulating the flow of verbal communication (Kendon, 1977). Indeed, Jones (2012) analysed gaze functions as a semiotic system using systemic-functional linguistics, and demonstrated that it can signal existence of an interpersonal relationship, signal attention or be a turn-taking resource. In a webconferencing setting, Satar (2013) discussed how gaze behaviour of language learners differ from that in face-to-face settings and identified five types of gaze in learner interactions: fixed, free, strategic, averted and directed gaze.

Proxemics describes the interpersonal spatial behaviour between people (Anderson, 2008) or that individuals take up with respect to relevant objects (Norris, 2009). Proxemic behavior offers insights into the kinds of social interactions being performed and is related to the action in the interaction environment (Hall, 1974). In our work, proxemics refers above all to the distance a participant places between himself and his webcam.

Within a multimodal (inter)action approach, new patterns of gaze and proxemics can be observed in online video-mediated communication as "the illusion of a face-to-face conversation 
dissolves as soon as video-specific resources are unpacked" (Sindoni, 2013: 51). This is also true of gestures that must be framed in the webcam and held long enough to be perceived in order to be valuable for mutual comprehension (Guichon \& Wigham, 2016).

It is important to note here that CA has been used in previous studies on instructiongiving sequences for fine-grained analysis (Markee, 2013, 2015a; Seedhouse, 2008). Although we are not following a CA approach, we do engage with some of its terms and concepts to underpin our explanations when analysing the verbal mode, such as markers, fillers, pauses and side-sequences. We also use concepts from other fields, e.g. interactional order introduced by Scollon \& Scollon within the concept of geosemiotics (See Lamy \& Flewitt, 2011 for an operationalization of geosemiotics in multimodal analysis of online conversations.)

In our context, it is useful to clarify how multimodal (inter)action analysis differs from a CA approach. As Jewitt, Bezemer and O'Halloran (2016) explain, whilst CA aims "to recognize social 'order' in the ways in which people organize themselves in and through interaction ... [b]ased on the notion of sequential action [in which e]ach social action is understood in relation to the action that preceded and followed", multimodal (inter)action analysis moves the focus away from language to "explore how a variety of semiotic resources are brought into and are constitutive of social interaction, identities and relations" (p.132).

\subsection{Data analysis procedures}

As a first analysis step, the different participants' webcam videos were imported into the transcription software ELAN (Sloetjes \& Wittenburg 2008). The spoken interaction was then transcribed. Using the timestamps created in Visu, the parallel text chat logs were synchronized with these transcriptions. 
The second analysis step was to isolate instruction-giving sequences for the role-play task. This was achieved by identifying the segments of the session allocated to the role-play task using trainees' lesson plans and then marking teacher trainees' talk for transition into task and for different fragments of the instruction-giving sequence drawing on the various segments described by Markee (2015a). Trainees did not deliver instructions as a monologue; thus, our segments also included learners' responses to instructions. Although the sequential, moment-by-moment analysis of talk-in-interaction in multimodal instruction-giving sequences is beyond the scope of this study, we acknowledge that as an important focus for further research.

Thirdly, using a separate tier in ELAN, co-verbal acts ${ }^{4}$ were isolated and described. These were not coded based on a pre-defined annotation grid which the authors felt might skew their interpretations. Rather, detailed textual descriptions were written for these acts to allow for a fine-grained, qualitative analysis of the interactions. The descriptions focused on participants' use of gestures; changes in posture and proxemics (when a participant moved closer to or further away from the webcam); whether gaze was directed towards one area of the screen in particular, towards the keyboard/desk or outside of the webcam frame; head movements (shaking, tilting, nodding); and salient facial expressions including frowning, smiling and raised eyebrows.

\section{Analysis}

In the analysis that follows, we present the highlights of a case-by-case presentation in order to focus on how different trainees give task instructions for a role-play rehearsal task and draw upon multimodal resources in doing so. This allows us to underline differences and

${ }^{4}$ Tellier (2017) defines co-verbal acts as spontaneously produced gestures and body movements that, when combined with speech, represent a single unit of meaning. They most often complete the verbal utterance or reinforce key elements in the verbal utterance. In certain cases they can also oppose the verbal utterance. They are distinct from non-verbal acts, which include movements and extra-communicative gestures that do not contribute to the meaning-making unit e.g. a participant pushing his hair behind his ear. 
similarities in the three trainees' approaches. An extract exemplifying the details of the analysis process is provided in Appendix 1; full analysis protocols are available on request. In the online version of this paper, video extracts of the data are available in parallel to the excerpts in which words in bold refer to the numbered still images included. Appendix 2 details the conventions used in the excerpts.

\section{1 Gaze, reduced proximity and pre-emptive vocabulary (Samia)}

Excerpts 1 and 2 come from our first case, Samia. Excerpt 1 begins with Samia's framing of the instruction with a marker (donc) and a filler (euh:) followed by the vocative (Sean) and assigning him the role of a co-worker. The trainee's gaze (images 1.1-1.5) shifts back and forth between the task resources (images 1.1, 1.3 and 1.5) and learners' images (images 1.2 and 1.4) and her gaze is directed towards learner images when she uses their names (vocatives). Samia assigns Angela's role in relation to Sean's role while she is still addressing Sean. Indeed, the orchestration of the different semiotic modes demonstrates contrasting forms of address.

Although the verbal utterance is addressed to Sean, the gaze shift towards Angela allows the trainee to address Angela visually and assign Angela her role, whilst verbally informing Sean.

\section{Excerpt 1}

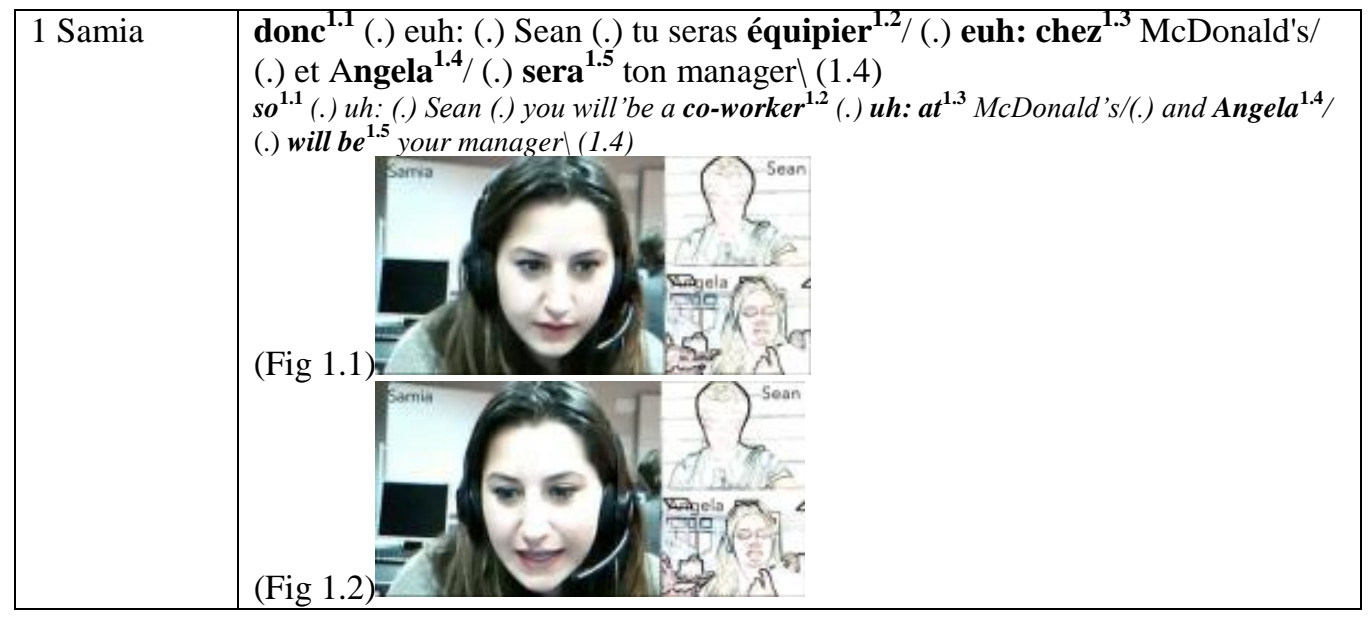




\begin{tabular}{|c|c|}
\hline 2 Samia & $\begin{array}{l}\text { vous savez ce que c'est un manager }(1.8) \\
\text { do you know what it is a manager }(1.8)\end{array}$ \\
\hline & lines 3-6 \\
\hline 7 Samia & $\begin{array}{l}\text { oui/ c'est quoi un équipier (.) chez McDonald's ( } 0.8) \\
\text { yes/what's a co-worker (.) at McDonald's ( } 0.8)\end{array}$ \\
\hline 8 Sean & $\begin{array}{l}\text { eh: (4.6) ((keystrokes)) } \\
\text { eh: (4.6) }\end{array}$ \\
\hline $\begin{array}{l}9 \text { Chat } \\
\text { (Samia) }\end{array}$ & $\begin{array}{l}\text { Équipier } \\
\text { Co-worker }\end{array}$ \\
\hline 10 Sean & $\begin{array}{l}\text { oh l'équipier: euh: les équipiers jouent le rôle de: }(0.5) \\
\text { oh the co-worker: } \text { uh: the co-workers play the role of: }(0.5)\end{array}$ \\
\hline 11 Sean & $\begin{array}{l}\text { les: (2.0) gens normales/ (0.4) gens (normal; normaux) (1.6) ((keystrokes)) } \\
\text { the (2.0) normal people/ }(0.4) \text { people normal }(- \text { sing }) \text { normal }(-p l)(1.6)\end{array}$ \\
\hline 12 Samia & $\begin{array}{l}\operatorname{des} /(2.0) \\
\text { somel }(2.0)\end{array}$ \\
\hline 13 Sean & $\begin{array}{l}\text { les gens en général/ (.) les employés/ }(0.7) \\
\text { the people in general/ (.) the employees/ }(0.7)\end{array}$ \\
\hline 14 Samia & $\begin{array}{l}\text { voilà c'est ça ce sont des employés très bien }{ }^{1.6}(1.2) \\
\text { there you go that's it they are the employees very good }{ }^{1.6}(1.2)\end{array}$ \\
\hline 15 Samia & $\begin{array}{l}\text { ((inbreath, change in gaze, reading instructions)) } \\
\text { donc }{ }^{1.7} \text { ensemble vous allez réfléchir tous les deux/ (0.6) à une nouvelle } \\
\text { formule pour les gouters d'anniversaire } \\
\text { sol.7 together you're going to think both of you/ (0.6) of a new formula for the birthday } \\
\text { parties }\end{array}$ \\
\hline
\end{tabular}


Lines 2-13 comprise two side sequences ${ }^{5}$ that consist of pre-emptive vocabulary checks to clarify the meaning of the words manager and co-worker, which are key words for understanding the task roles. Samia facilitates meaning negotiation by switching to the written mode as a semiotic resource (line 9) and by not interrupting Sean's turns too quickly demonstrated by the pauses in his turns (e.g. lines 10-11).

In lines 14 and 15, Samia manages a shift in focus from meaning negotiation for key vocabulary items to task instructions by a change in gaze (images 1.6 and 1.7) and a marker $($ donc $)$. Her gaze back to the left-hand side of the screen that accompanies this shift to instructions manifests her need to read the instructions in order to follow the lesson plan.

Between Excerpt 1 and 2, Samia continues in the audio modality with task instructions and pre-emptively checks the meaning of birthday parties (context) and list (expected outcome) whilst putting these target lexical items into text chat.

\section{Excerpt 2}

\begin{tabular}{|c|c|}
\hline 1 Samia & $\begin{array}{l}\text { donc d'après vous qu'est-ce qu'i faudrait faire }(2.8) \\
\text { so in your opinion what do you ha have to do } \backslash(2.8)\end{array}$ \\
\hline \multicolumn{2}{|r|}{$\begin{array}{ll}\text { lines 2-7 } \\
\end{array}$} \\
\hline 8 Angela & $\begin{array}{l}\text { d'abord il faut réfléchir ce qu'on fait maint nant/ (0.3) } \\
\text { first of all we need to think about what we'll do now/ }(0.3)\end{array}$ \\
\hline 9 Angela & $\begin{array}{l}\text { pour les: euh goûts d'anniversaire/ ( } 0.5) \\
\text { for the: uh birthday tastes/ }(0.5)\end{array}$ \\
\hline 10 Samia & $\begin{array}{l}\text { d'accord/ (0.5) } \\
\text { okay/(0.5) }\end{array}$ \\
\hline 11 Angela & $\begin{array}{l}\mathrm{mh}:(3.1) \\
m h:(3.1)\end{array}$ \\
\hline 12 Angela & $\begin{array}{l}\text { après: peut-être }(0.7) \\
\text { afterwards: maybe }(0.7)\end{array}$ \\
\hline
\end{tabular}

\footnotetext{
5 "In the course of some on-going activity (for example, a game, a discussion), there are occurrences one might feel are not "part" of that activity but which appear to be in some sense relevant. Such an occurrence constitutes a break in the activity-specifically, a "break" in contrast to a "termination"; that is, the on-going activity will resume. This could be described as a "side sequence within an on-going sequence"". (Jefferson, 1972: 294).
} 


\begin{tabular}{|c|c|}
\hline 13 Angela & $\begin{array}{l}\text { mh: de }(1.7) \\
\text { mh: to }(1.7)\end{array}$ \\
\hline 14 Angela & $\begin{array}{l}\text { changer }^{2.2} \text { ce qu'on veut changer et euh: }(0.4) \\
\text { change }^{2.2} \text { what we want to change and uh: }(0.4)\end{array}$ \\
\hline 15 Angela & $\begin{array}{l}\text { demander aux gens/ (.) ce qu'ils veulent changer/ (0.2) } \\
\text { ask people /(.) what they want to change/ }(0.2)\end{array}$ \\
\hline & lines $16-17$ \\
\hline 18 Samia & $\begin{array}{l}\text { oui: on pourrait faire ça:/ (1.0) } \\
\text { yes: we could do that:/(1.0) }\end{array}$ \\
\hline
\end{tabular}

Once key vocabulary for the task is clarified, Samia asks her learners what they need to do to complete the task (line 1) to either launch the task or to concept-check the instructions. Angela states that the learners need to think about what they will do for the birthday parties (lines 8-9). Samia uses the d'accord in line 10, to acknowledge Angela's contribution and comprehension but also to elicit more from the learners (rising intonation) by indexing listenership. Image 2.1 exemplifies her proximity to the screen up until line 10. Once Angela is engaged and seems to have started the task, Samia's change in proximity shows the learners, in the visual mode (line 14, image 2.2), that she no longer wishes to orchestrate the interaction and confirms Angela's move into her role.

\subsection{Proximity and incomplete instructions (Etienne)}

In this second case, role allocation comes as an interruption during a period when the learners are already engaged in a task preparation phase. At the beginning of excerpt $3 \mathrm{a}$ (lines 112), the trainee, Etienne, checks learners' understanding and provides explanation of the concept of birthday parties at fast-food outlets to set the context. He then gives the instructions that he will be the manager (lines 13-14) indexing his role allocation with a marker (donc). Etienne also illustrates how the learners will accomplish the task by providing examples of the concepts they 
might want to talk about (lines 16-19) and employs pauses and fillers (lines 16-19) to keep the floor during this stage. He announces in line 20 that he will allocate two minutes of preparation time and, after a pause, invites learners to ask any questions they might have (line 21) indexing this invitation with the marker $e$.

\section{Excerpt 3a}

\begin{tabular}{|c|c|}
\hline 1 Etienne & $\begin{array}{l}\text { euh: donc euh: }(0.6) \\
\text { uh: so uh: }(0.6)\end{array}$ \\
\hline 2 Etienne & $\begin{array}{l}\text { je sais pas si: vous connaissez c'principe (1.7) } \\
\text { I don't know if: you know the prinicple (1.7) }\end{array}$ \\
\hline 3 Etienne & $\begin{array}{l}\text { hum: d'anniversaire à mcdonald's } \backslash \\
\text { hum: of birthdays at mcdonald's } \backslash\end{array}$ \\
\hline \multicolumn{2}{|r|}{ lines 4-12 ((Etienne explains the concept of birthdays at mcdonald's)) } \\
\hline 13 Etienne & $\begin{array}{l}\text { [donc ça] c'est votre projet/ (1.1) } \\
\text { [so that] that's your project/(1.1) }\end{array}$ \\
\hline 14 Etienne & $\begin{array}{l}\text { et moi j'suis votre manager/ et je vais vous demander euh: } \\
\text { and me I'm your manager/and I'm going to ask you uh: }\end{array}$ \\
\hline 15 Conor & $\begin{array}{l}\text { d'accord }(0.5) \\
\text { okay }(0.5)\end{array}$ \\
\hline 16 Etienne & $\begin{array}{l}\text { euh: comment vous faites pour réaliser ce projet } \backslash(0.8) \\
\text { uh: what you are going to do to complete this project }(0.8)\end{array}$ \\
\hline 17 Etienne & $\begin{array}{l}\text { est-ce que vous avez des idées euh (0.4) euh: }(0.4) \\
\text { do you have any ideas } u h(0.4) u h:(0.4)\end{array}$ \\
\hline 18 Etienne & $\begin{array}{l}\text { euh quelles activités vous voulez mettre en place }(0.5) \\
\text { uh what activities you want to put into place }(0.5)\end{array}$ \\
\hline 19 Etienne & $\begin{array}{l}\text { euh quelles actions vous voulez faire (.) voilà (.) c'est ça (1.3) } \\
\text { uh what things you want to do (.) there you go (.) that's it (1.3) }\end{array}$ \\
\hline 20 Etienne & $\begin{array}{l}\text { vous pouvez réflechir une minute et après je vous écoute (2.8) } \\
\text { you can think for a minute and afterwards I'll listen to you (2.8) }\end{array}$ \\
\hline 21 Etienne & $\begin{array}{l}\text { et si vous avez des questions (1.0) } \\
\text { and if you have any questions (1.0) }\end{array}$ \\
\hline 22 Sophie & $\begin{array}{l}\text { non }(4.4) \\
\text { non }(4.4)\end{array}$ \\
\hline 23 Etienne & $\begin{array}{l}\text { t'as compris Sophie }(0.3) \\
\text { did you understand Sophie (0.3) }\end{array}$ \\
\hline 24 Sophie & $\begin{array}{l}\text { oui oui }(1.3) \\
\text { yes yes }(1.3)\end{array}$ \\
\hline 25 Etienne & $\begin{array}{l}\text { ok }(8)^{3.1} \\
o k(8)^{3.1}\end{array}$ \\
\hline 26 Etienne & $(44)^{3.2}$ ((until he starts speaking again in line 33, Excerpt 3b)) \\
\hline
\end{tabular}




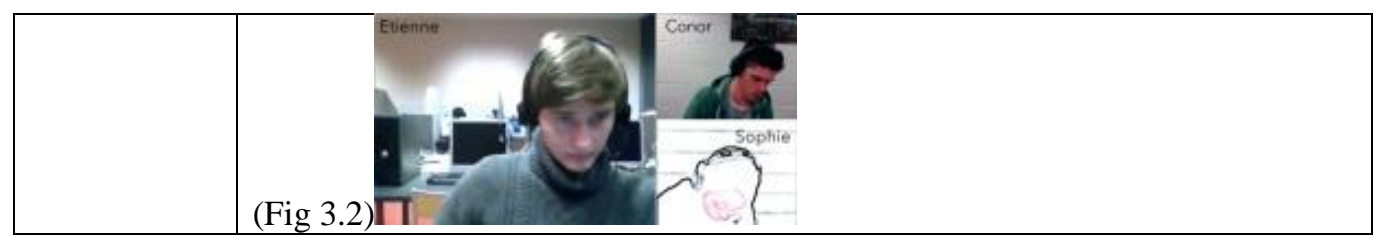

The trainee's head-down posture during the preparation time (lines 25-26) recurs throughout Etienne's different instruction phases. Several instances show that by looking downwards and away from the camera, he tries to leave the interactional order despite still being present in the visual mode. This posture change supports turn allocation indicating to his learners that he is not going to attempt to take the floor and provides a clear visual cue to the division between teacher instruction-giving exchange and the learner task preparation phase. However, no role allocation has been accomplished at this stage.

Between extracts 3a and 3b, Etienne's silence continues (lines 27-32). During this time, Conor asks a task-related question (line 28), but Etienne ignores it both verbally and nonverbally.

\section{Excerpt 3b}

\begin{tabular}{|c|c|}
\hline 33 Etienne & $\begin{array}{l}\mathbf{o h}^{3.3} \mathrm{j}^{\prime} \text { ai oublié de préciser que vous êtes euh une équipe (1.0) } \\
\text { oh }^{3.3} \text { Iforgot to specify that you are uh a team (1.0) } \\
\text { Etienne }\end{array}$ \\
\hline 34 Etienne & $\begin{array}{l}\text { vous vous- vous êtes- vous travaillez ens- enfin: } \backslash(0.6) \\
\text { you you- you are- you work tog-in fact: } \backslash(0.6)\end{array}$ \\
\hline 35 Etienne & $\begin{array}{l}\text { vous [vous- vous] avez tous les deux des idées mais vous êtes euh } \\
\text { you [you- you] both have ideas but you are uh }\end{array}$ \\
\hline 36 Conor & $\begin{array}{l}\text { [ensemble] }(0.9) \\
\text { [together] }(0.9)\end{array}$ \\
\hline 37 Etienne & $\begin{array}{l}\text { OUAI: } \backslash \text { ouai ouai }(0.7) \\
Y E A H: \backslash \text { yeah yeah }(0.7)\end{array}$ \\
\hline 38 Sophie & $\begin{array}{l}{[((\text { rire })) \text { ok }]} \\
{[((\text { laugh })) \text { ok }]}\end{array}$ \\
\hline 39 Etienne & $\begin{array}{l}\text { c'est pl[us- c'est plus pratique] } \\
\text { it's mo[re-it's more practical] }\end{array}$ \\
\hline
\end{tabular}




\begin{tabular}{|l|l|}
\hline 40 Conor & {$[$ (inaud) $](0.6)$} \\
\hline 41 Etienne & $\begin{array}{l}\text { donc euh Sophie tu vas- tu vas proposer tes idées à } \\
\text { so uh Sophie you are-you are going to suggest your ideas to }\end{array}$ \\
\hline 42 Conor & $\begin{array}{l}\text { hum: }(0.3) \\
\text { hum: }(0.3)\end{array}$ \\
\hline 43 Etienne & $\begin{array}{l}\text { Conor }(1.7) \\
\text { Conor }(1.7)\end{array}$ \\
\hline 44 Sophie & $\begin{array}{l}\text { HUM: je pense que: nous devons }:: \\
\text { HUM: } \text { I think that: } \text { we should: }\end{array}$ \\
\hline
\end{tabular}

In excerpt 3b, Etienne's change in posture (image 3.3) shows that he has returned to the interactional order to complete the role allocation stage. Etienne admits that he has not given clear instructions for the pair work (line 33) and allocates roles in lines 34-35. A check question is offered by Conor (line 36), allowing the pair-work aspect to be clarified and justified by the trainee (line 39). The pair-work task then commences, following clear turn allocation with the use of learner names (lines 41 and 43). Thus, the actual role allocation stage happens as an interruption during task preparation time indexed with fillers (e.g. oh in line 33), pauses (end of lines 33 and 34) and a marker donc (line 41).

\subsection{Technical problem, gaze and gestures (Mélissa)}

Our next case, Mélissa, starts her instruction-giving sequence with only one learner because the other is experiencing technical problems and it had been almost 13 minutes into the session.

\section{Excerpt 4}

\begin{tabular}{|l|l|}
\hline 1 Mélissa & $\begin{array}{l}\text { donc TOI (0.4) } \\
\text { so } Y O U(0.4)\end{array}$ \\
\hline 2 Mélissa & $\begin{array}{l}\text { tu vas travailler chez: McDonald/ (1.2) } \\
\text { you are going to work at: McDonald/ }(\mathbf{1 . 2})^{4.1}\end{array}$ \\
& Maissas
\end{tabular}




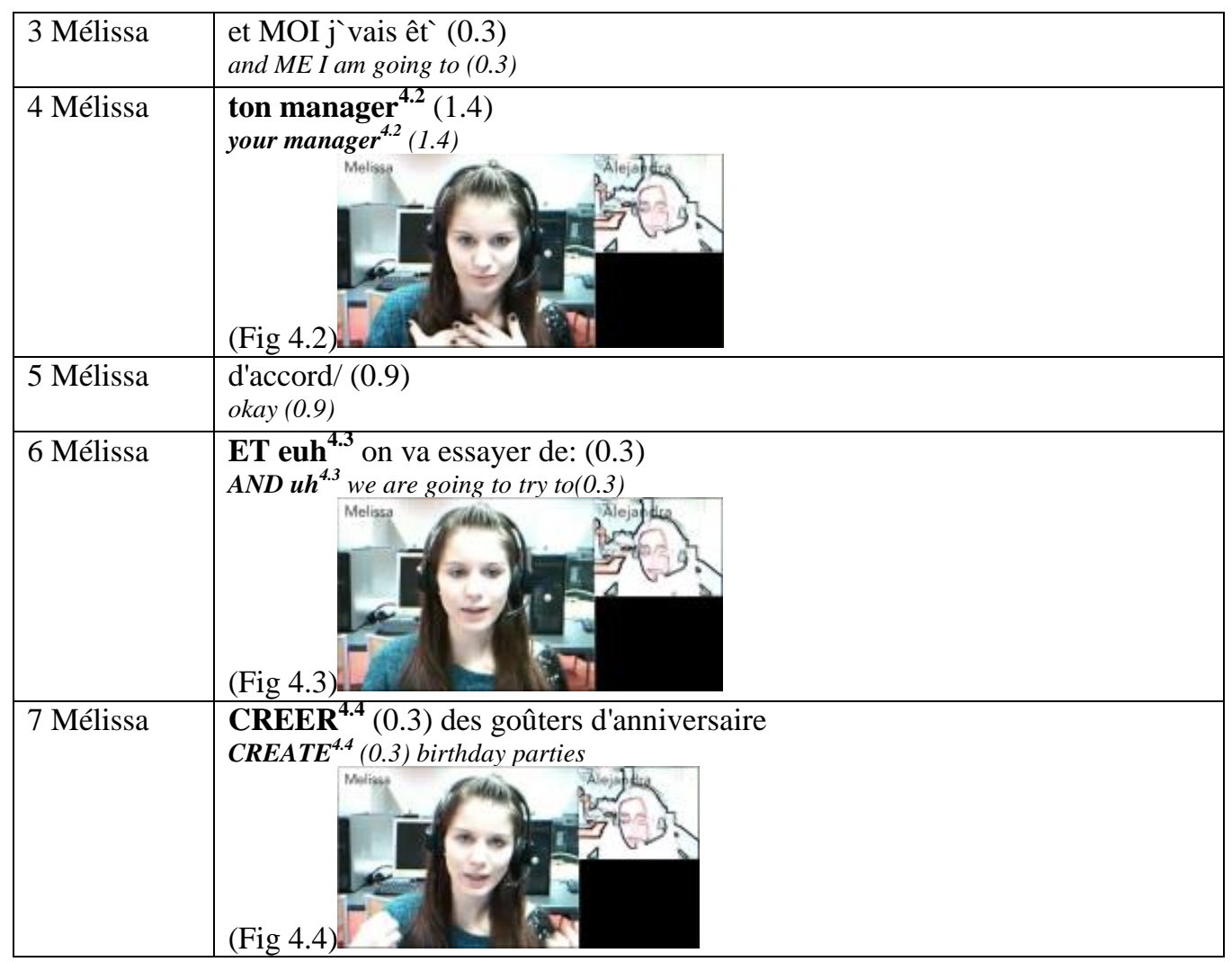

In excerpt 4, Mélissa begins her instruction-giving sequence by differentiating between the roles of the manager and the co-worker. Co-verbally, the excerpt demonstrates the trainee's awareness of both the visual and the verbal modes. In lines 1-2, she designates the student as the co-worker by stressing the word you and pausing and looking up directly into the webcam. The visual mode and the pause at the end of line 2 mark the end of the learner's role allocation. Similarly, in lines 3-4, Mélissa explains her role as the manager with stress on $m e$ and with a sustained deictic gesture starting on this word and ending in line 4. She uses a marker (d'accord) in line 5 to mark the end of this stage (i.e. role allocation). In lines 6-7, Mélissa explains what they will do to accomplish the task and skilfully orchestrates the visual and the verbal modes again by employing a marker, a filler and gaze change to introduce a new stage and by using direct gaze, pause, word stress and gesture to clarify key words. 
In the session data for this trainee, however, there is a second role allocation stage.

Mélissa's second learner, Ana, reconnects to the platform. After brief salutations, the trainee asks the first learner to explain the task to her peer (excerpt 5, line 1).

\section{Excerpt 5}

\begin{tabular}{|c|c|}
\hline 1 Mélissa & $\begin{array}{l}\text { euh: (0.4) Alejandra est-ce que tu peux expliquer à Ana/ }(0.4) \text { ce qu'on va faire/ } \\
(0.5) \\
\text { uh: (0.4) Alejandra can you explain to Ana/ (0.4) what we're going to do/ }\end{array}$ \\
\hline 2 Alejandra & $\begin{array}{l}\text { d'accord (0.4) hém: }(0.3) \text { nous: devons HEM: }(0.5) \text { faire [un] liste } /^{5.1}(0.4) \text { des: } \\
\text { okay (0.4) erm: (0.3) we; have to ERM: }(0.5) \text { make [a] list }\left.\right|^{5.1}(0.4) \text { of } \\
\text { Meliass }\end{array}$ \\
\hline 3 Ana & $\begin{array}{l}\mathrm{mh} \mathrm{mh} /(0.3)^{5.2} \\
\operatorname{mh~} \operatorname{mh}(0.3)^{5.2} \\
\text { Meliso }\end{array}$ \\
\hline 4 Alejandra & $\begin{array}{l}\text { hé: pour organiser/ (0.6) organiser UN anniversaire à McDonald's } \backslash(1.4) \\
\text { er: to organise/ }(0.6) \text { to organise A birthday party at McDonald's } \backslash \text { (1.4) }\end{array}$ \\
\hline 5 Alejandra & \begin{tabular}{l} 
[et]: [Méli]ssa/ est lé manager\} $\\
{\text { [and]: [Méli]ssa/ is the manager }}$ \\
\hline 6 Mélissa & $\begin{array}{l}\text { [oui] [c'est ça] }(1.8) \\
\text { [yes] [that's it] }(1.8)\end{array}$ \\
\hline 7 Ana & $\begin{array}{l}\text { ah ok une }{ }^{5.3} \text { LISTE (0.2) pour euh }{ }^{5.4} \mathbf{h u m :}^{\mathbf{5 . 5}} \text { (1.6) une liste pour QUOI/ } \\
\text { ah ok } \boldsymbol{a}^{5.3} \text { LIST (0.2) to } \boldsymbol{u h}^{5.4} \mathbf{u h}^{5.5} \text { (1.6) a list for what/ }\end{array}$ \\
\hline
\end{tabular}
\end{tabular}




\begin{tabular}{|c|c|}
\hline 8 Alejandra & $\begin{array}{l}\text { je n'écoute (inaud) } \\
\text { I don't hear (inaud) }\end{array}$ \\
\hline 9 Mélissa & $\begin{array}{l}\text { [pour organiser] oui tu peux répéter Alejandra } \\
\text { [to organise] yes can you repeat Alejandra }\end{array}$ \\
\hline 10 Alejandra & $\begin{array}{l}\text { hé Ana je ne t'écoute pas } \\
\text { hey Ana I can't hear you }\end{array}$ \\
\hline 11 Ana & $\begin{array}{l}\text { hum euh qu'est-ce que c'est le liste (1.4) qu'est-ce qu'on DOIT eu (0.6) faire } \\
\text { wh uh what is it the list (1.4) what do we HAVE uh (0.6) to do }\end{array}$ \\
\hline 12 Alejandra & $\begin{array}{l}\text { les [listes pour] organiser un anniversaire } \\
\text { the [lists to] organise a birthday party] }\end{array}$ \\
\hline 13Ana & $\begin{array}{l}\text { [quelle liste] (1.0) euh (3.6) AH: }(0.3) \text { organiser un anniversaire à mac DO } \\
\text { what list (1.0) uh (3.6) AH: (0.3) to organize a birthday party at mac DO }\end{array}$ \\
\hline 14Alejandra & $\begin{array}{l}\text { à mac do[nald }] \\
\text { at macdo[nald }]\end{array}$ \\
\hline 15 Mélissa & $\begin{array}{l}\text { [alors] en fait (0.8) euh: moi je suis censée être le manager }{ }^{5.6} \text { mais en fait } \\
\text { l'intérêt c'est que vous deux/ vous discutiez toutes les deux entre vous/ (1.1) } \\
\text { [so] in fact (0/8) uh: me I'm meant to be the manager }{ }^{5.6} \text { but in fact the interest is for you two/ to } \\
\text { speak together both of you between you/ (1.1) } \\
\text { (Fig 5.6)isso }\end{array}$ \\
\hline
\end{tabular}

As excerpt 5 shows, the trainee moves into a 'listening pose' (image 5.1) after the learner takes the floor. Her move away from the screen, while cupping her headphones (image 5.2), indicates to the learners that she is attentive to the peer explanation and does not intend to take the floor. In lines 2, 4 and 5, Alejandra rephrases the task instructions, positioning herself as expert, but does not explain the learners' roles of being co-workers as Mélissa had not explained this to her because the initial trainee explanation only involved one learner. Whilst Mélissa confirms the learner's explanation (line 6), Ana initially signals her understanding, repeating the key word 'list' but then hesitates (line 7). Alejandra is attentive during this exchange as shown by her proxemic engaged-response cues. During Ana's first hesitation signal, Alejandra moves 
proxemically closer towards her webcam and both the trainee and Alejandra centre their gazes (Images 5.3 and 5.4). Alejandra's facial expression shows she squints at the screen. Ana's second hesitation marker in line 7 is accompanied by Alejandra moving even closer towards the screen and placing her right hand on her headphones (Image 5.5a). It appears that Ana interprets this change in posture as a manifestation of her peer's incomprehension and rather than attempt to explain the function of the list prefers to ask her peer a check question (line 7: "a list for what), which reinforces Alejandra's position as 'expert' in this exchange. In line 9, Mélissa attempts to respond to Ana's question, but given Alejandra's verbalisation of a technical issue, she then invites Alejandra to re-explain. Alejandra suggests verbally that there is a technical issue with the audio modality (lines 8 and 10) which prompts Ana to reformulate her check question (line 11). Alejandra, again in the role of expert, answers this second check question.

Following this peer-to-peer interaction, in line 15, Mélissa clarifies her role as the manager during which she uses direct gaze, word stress and an emblem gesture (image 5.6) to indicate her pretend role. At this stage, the learners' roles are still not clearly established, which prompts Ana to request task clarification later on in the sequence (excerpt 6).

\section{Excerpt 6}

\begin{tabular}{|c|c|}
\hline 1 Ana & $\begin{array}{l}\text { [mais est-ce que- est-ce que nous sommes euh:] (0.6) } \\
\text { [but are are we are erm:] (0.6) }\end{array}$ \\
\hline 2 Ana & $\begin{array}{l}\text { uh est-ce que nous doi: }(0.3) \\
\text { do we have to }(0.3)\end{array}$ \\
\hline $\begin{array}{l}3 \\
\text { Ana }\end{array}$ & $\begin{array}{l}\text { euh organiser une: anniversaire pour une copain de } \text { nous }^{6.1} \text { à } \mathbf{~ m a c D O}^{6.2}(0.4) \\
\text { uh organise a: birthday party for a friend of our's }{ }^{6.1} \text { at macDO }{ }^{6.2}(0.4) \\
\text { Melsso }\end{array}$ \\
\hline 4 Mélissa & $\begin{array}{l}\text { non } \\
\text { no }\end{array}$ \\
\hline 5 Ana & $\begin{array}{l}\text { ou est-ce que c'est }(0.7) \\
\text { or is it that it is }(0.7)\end{array}$ \\
\hline
\end{tabular}




\begin{tabular}{|c|c|}
\hline 6 Mélissa & $\begin{array}{l}\text { vous vous travaillez chez m- } \\
\text { you you work at m- }\end{array}$ \\
\hline & lines 7-12 \\
\hline 12 Mélissa & $\begin{array}{l}\text { d'accord }^{6.3} /(0.4) \\
\text { okay }^{6.3} /(0.4)\end{array}$ \\
\hline 13 Mélissa & $\begin{array}{l}\text { donc euh qu'est-ce que vous pourrez }(0.2) \mathrm{mh}(0.3) \\
\text { so uh what can you }(0.2) \mathrm{mh}(0.3)\end{array}$ \\
\hline 14 Mélissa & $\begin{array}{l}\text { qu'est-ce que vous POUVEZ proposer }(0.5) \\
\text { what COULD you suggest }\end{array}$ \\
\hline 15 Mélissa & $\begin{array}{l}\text { à des clients qui veulent fêter leur anniversaire chez McDonald } \backslash(0.2) \\
\text { to clients who want to celebrate their birthday at McDonald }(0.2)\end{array}$ \\
\hline 16 Alejandra & $\begin{array}{l}\text { je pense que la première chose est-ce que nous: }(0.4) \\
\text { I think that the first thing is that we: }(0.4)\end{array}$ \\
\hline
\end{tabular}

Just before excerpt 6 commences, the trainee attempts to launch the task. However, Ana asks for clarification of her role (lines 1,2,3 and 5) during which time Mélissa visually indicates being attentive with her listening posture (image 6.1). Ana's clarification request is accompanied in the visual mode by two deictic gestures to signify nous and macDO (images 6.1 and 6.2). The learner's facial expressions and puzzlement also confirm her gestures. Between lines 6-11, Mélissa tries to explain the learner roles. This is followed by a marker and short pause (d'accord, line 12). The latter is not taken up by the learners as a transition point as was the case in excerpt 2. Rather, the shorter pause appears to punctuate the closure of this stage of the instruction-giving sequence. Although Ana stills seems unclear about what to do (image 6.3a), Mélissa embarks on 
explaining what the learners will do to accomplish the task (lines 13-15) by indexing this with a filler $(d o n c)$ in line 13. The activity then begins (line 16). However, Ana does not interact verbally for another two minutes, leaving her peer to lead the interaction and, it appears, she only gains understanding through following her peer's lead on the task.

\section{Findings and Discussion}

Using three cases, we have investigated instruction-giving practices of language teacher trainees in an online role-play task. With Samia (excerpts 1 and 2), we demonstrated the trainees' use of gaze and vocatives in role allocation. The data also exemplified her step-by-step approach to giving task instructions, concept checking each key vocabulary item through elicitation and text chat function. Samia was able to express that she moved into her role as the manager by reducing her proximity to the screen (excerpt 2, image 2.2).

Etienne's case (excerpts $3 a$ and $3 b$ ) demonstrated the use of pre-emptive vocabulary explanation to set the task context. His data also illustrated what happened when task instructions, especially role allocation was incomplete and how the resulting confusion and uneasiness were resolved. Although Etienne clearly gave time for task preparation, he failed to indicate how learners would accomplish the task (pair work). He also maintained his head-down posture throughout this preparation time, indicating he was outside the interactional order. Indeed, during this time he ignored a learner-question about the task. Learners were then not willing to either break the silence or launch the task until Etienne clarified role allocation.

Mélissa's case (excerpts 4, 5 and 6) illustrated, first, use of gaze and both deictic and emblematic gestures in role allocation; second, gaze shift between activity resources, learner's image and webcam; third, trainee's awareness that she can use the visual mode to stress certain 
key words and fourth, use of verbal mode to punctuate the different stages in the activity instructions. The case also demonstrated the trainee's strategy of peer explanation to encourage student-student interaction once the technical issue of her second learner has been resolved. In the visual mode, the data showed how she adopted a listening posture during this sequence. The data also exemplified that if one aspect of the instruction, i.e. learner roles was not covered in the peer explanation, this could lead to misunderstanding.

In our analysis, we looked for how trainees employed semiotic resources available in the online environment in their instructions, specifically when they (1) marked the beginning, different fragments and end of instructions, (2) allocated roles, and (3) introduced key vocabulary items. Tables 4-7 summarise the findings of our case-by-case findings. These indicate that teacher trainees in our sub-corpus mostly used fillers, markers, pauses and gaze to signal either the beginning of instructions or the different fragments. In order to mark the end of the instructions and give the floor to learners, all teacher trainees employed a change in proximity, sometimes accompanied by gaze change, head movement or touching the headphones indicating a removal from the interactional order. Role allocation practices of the trainees varied (Table 6). While using vocatives seemed efficient in this context, this was often accompanied by subtle changes in gaze and use of gestures. We observed that peer explanation and forgetting to explain the roles at the right moment could be detrimental to task accomplishment and flow of interaction.

Table 4 Signalling beginning of instructions and instruction fragments

\begin{tabular}{|l|l|l|}
\hline $\begin{array}{l}\text { marker - donc } \\
\text { filler } \\
\text { gaze }\end{array}$ & Samia & $\begin{array}{l}\text { excerpt 1, lines 1, 15; excerpt 2, line 1 } \\
\text { excerpt 1, line 1 } \\
\text { excerpt 1, line 14 }\end{array}$ \\
\hline $\begin{array}{l}\text { marker - donc } \\
\text { pauses \& fillers }\end{array}$ & Etienne & $\begin{array}{l}\text { excerpt 3, lines 13, 41 } \\
\text { excerpt 3, lines 16-19, 33, 41 }\end{array}$ \\
\hline
\end{tabular}




\begin{tabular}{|c|c|c|}
\hline marker $-e t$ & & excerpt 3 , line 21 \\
\hline $\begin{array}{l}\text { marker - donc } \\
\text { marker - d'accord } \\
\text { marker - alors } \\
\text { fillers } \\
\text { silence to punctuate with direct gaze }\end{array}$ & Mélissa & $\begin{array}{l}\text { excerpt } 4 \text {, line } 1 \text {; excerpt } 6 \text {, line } 13 \\
\text { excerpt } 4 \text {, line } 5 \\
\text { excerpt } 5 \text {, line } 7 \\
\text { excerpt } 4 \text {, line } 6 \text {; excerpt } 5 \text {, line } 1 \\
\text { excerpt } 4 \text {, lines } 2,7\end{array}$ \\
\hline
\end{tabular}

Table 5 Signalling end of the instruction-giving sequence: the listening posture

\begin{tabular}{|l|l|l|}
\hline reduced proximity and central gaze & Samia & excerpt 2, line 14 \\
\hline $\begin{array}{l}\text { removal from interactional order: } \\
\text { increased proximity and head down } \\
\text { reduced proximity and gaze away }\end{array}$ & Etienne & $\begin{array}{l}\text { excerpt 3, line 25 } \\
\text { excerpt 3, line 26 }\end{array}$ \\
\hline reduced proximity \& holding headphones & Mélissa & $\begin{array}{l}\text { excerpt 5, lines 2, 3; excerpt 6, } \\
\text { line 3 }\end{array}$ \\
\hline
\end{tabular}

Table 6 Role allocation

\begin{tabular}{|l|l|l|}
\hline $\begin{array}{l}\text { vocatives } \\
\text { change in gaze }\end{array}$ & Samia & $\begin{array}{l}\text { excerpt 1, line 1 } \\
\text { excerpt 1, lines 1, 15 }\end{array}$ \\
\hline interruption to silent work & Etienne & excerpt 3, lines 33-35 \\
\hline $\begin{array}{l}\text { peer explanation } \\
\text { deictic gestures } \\
\text { emblematic gestures }\end{array}$ & Mélissa & $\begin{array}{l}\text { excerpt 5, lines 1-4 } \\
\text { excerpt 4, line 4 } \\
\text { excerpt 5, line 7 }\end{array}$ \\
\hline
\end{tabular}

Table 7 Introduction of key vocabulary items

\begin{tabular}{|l|l|l|}
\hline $\begin{array}{l}\text { during instructions as a side-sequence } \\
\text { (pre-emptive): } \\
\text { elicitation with pause } \\
\text { use of text chat }\end{array}$ & Samia & $\begin{array}{l}\text { excerpt 1, lines 2-15 } \\
\text { excerpt 1, lines 8-9 }\end{array}$ \\
\hline $\begin{array}{l}\text { before instructions: } \\
\text { in the form of contextualising the task }\end{array}$ & Etienne & excerpt 3, lines 1-12 \\
\hline $\begin{array}{l}\text { during instructions: } \\
\text { direct gaze, pause, word stress \& gesture } \\
\text { direct gaze, word stress \& gesture }\end{array}$ & Mélissa & $\begin{array}{l}\text { excerpt 4, line 7; } \\
\text { excerpt 5, line 7 }\end{array}$ \\
\hline
\end{tabular}


All three trainees explained or checked the learners' understanding of key vocabulary items prior to or during instructions either in the verbal mode marked by pauses, word stress or through attempted direct gaze or in the written mode using text chat (Table 7). In language learning settings, explanation of key vocabulary items could be added as a seventh item to Markee's (2015b) fragments of instructions.

Moreover, these findings emphasise several multimodal resources employed in a variety of ways to aid instruction-giving. These include proximity, gaze, gestures, head movements and touch (touching head phones or other external objects). Although all teacher trainees in our study followed the same lesson plan and draft instructions, their actual instruction-giving practices varied considerably. Thus, while research on instructions which considers multimodal elements in the foreign language classroom is relatively recent (Seedhouse, 2008; Markee, 2015a), multimodal competence of online teachers in managing instruction-giving sequences also merits special attention.

Several pedagogical conclusions could be drawn from our analysis. First, it is clear that for better task administration, online language teachers need to demonstrate clear boundaries between instructions and beginning of the task; otherwise, due to reduced non-verbal cues, learners may be confused as to when to initiate the task. In a face-to-face classroom, teachers can signal end of instructions by mutual posture alignment (Hellermann \& Pekarek Doehler, 2010) or by altering their central position in the classroom. In online classes, some systems allow for the creation of break-out rooms (see Messina Dahlberg \& Bagga-Gupta, 2015; Martin, Parker \& Allred, 2013), where the tutor leaves the learners alone to complete the task. In the current context, however, where the trainees worked with a small number of learners online, they signalled task launch drawing on multimodal resources. Alternatively, in order to leave the floor 
for pair/group work, tutors could mute their webcams to indicate their removal from the interactional order.

Second, peer explanation of task requirements did not seem to work well in this context. Trainees need to pay extra attention to ensure that all steps of the instructions are covered by the learner who is explaining the task. As Seedhouse (2008) argues, instructions need to be "simple, clear and focused" (p. 53) where the shift in focus is clearly marked.

Third, pre-emptive introduction of key vocabulary items seemed to avoid problems during task completion. This was conducted by concept-checking of these key items by eliciting learner explanations and using text chat as required. Moreover, as the learners did not have access to shared resources (such as a whiteboard) or other semiotic resources (Hellermann \& Pekarek Doehler, 2010; Markee, 2015a; Seedhouse, 2008), visual and verbal punctuation of each fragment of the instructions was essential. In the online context, in order to compensate for the lack of other semiotic resources, teacher trainees can be advised to use an online whiteboard or the text chat functionality to outline task completion steps.

Finally, classroom research has demonstrated how teachers use gaze, pointing gestures and head nods to nominate next speakers (Kääntä, 2015). However, impossibility of efficiently using gaze in online conversations (Satar, 2013) and, in the context of online instruction-giving, for turn designation necessitated the use of gestures and vocatives in role allocation.

\section{Conclusion}

This paper underscores the need to increase language teachers' awareness of multimodal elements that are vital to instruction-giving sequences. Teachers should be prepared to effectively use online multimodal environments (Guichon \& Cohen, 2016) and be equipped with the 
knowledge and skills to deal with technical difficulties that might occur during instructions. These might include difficulties in directing attention of the learners to the resources needed for task accomplishment and explaining how the task will be accomplished using online resources. As such, task-based teaching competencies for teachers (Raith and Hegelheimer, 2010) should also include the ability to effectively harness the potential of available multimodal semiotic resources when giving task instructions.

Future studies can, thus, focus on the needs of the online context and explore differences in (multimodal) instruction-giving practices in online and face-to-face classrooms. Such research could help develop further guidelines to support language teachers' pedagogical competence. Further research exploring experienced online teachers' instruction-giving practices as well as effectiveness of instructions by associating task instructions and outcomes would also be worthwhile in providing exemplars of good practice for potential training tasks for future language teachers. Such research could either be oriented to an exploration of semiotic resources using multimodal (inter)action analysis (as is the case in the present study) or could employ CA as both a research tool and a pedagogical tool (see Seedhouse, 2008; Sert, 2013) with a focus on sequential actions and interactions between the teacher and the learners.

It should be noted that the quality of the recordings analysed in this study posed certain challenges. As the recordings were sometimes jerky with intermittent missing frames, soundpicture alignment was sometimes a limitation for gaze analysis. Moreover, this study has been primarily concerned with instruction-giving sequences in a role-play task. Although role-plays are considered an efficient type of rehearsal tasks (Nunan, 2004; Yen, Hou \& En Chang, 2015), their appropriateness to the online context could be questioned from a socio-cultural point of view given various cultural identities participants already bring to interaction (Guichon \& 
Nicolaev, 2011; Guichon, 2017). Therefore, further research could investigate instruction-giving practices in other types of tasks.

This study shows the value of adopting a multimodal (inter)action analysis approach to better understand online instruction-giving practices within a task-based language teaching framework. It exemplifies how trainee teachers use different semiotic resources at their disposal, including gaze, proximity, gesture and text chat, to punctuate different instruction-giving phases, allocate roles, deal with key vocabulary and manage task instructions when technical issues arise. The pedagogical conclusions arising from the analysis suggest that trainee teachers should be engaged more fully in harnessing the potential of semiotic resources during instruction-giving phases for webconferencing-supported language teaching.

\section{Appendix 1. Sample analysis procedure (Excerpt 1)}

Excerpt 1 begins with Samia's framing of the instruction with a marker (donc) and a filler (euh:) followed by the vocative (Sean) and assigning the role of a co-worker with future reference to role definition (you will be).

In line 1, Samia assigns Angela's role in relation to Sean's role while she is still addressing Sean. Her gaze (images 1.1-1.5) shifts back and forth between the task resources (images 1.1, 1.3 and 1.5) and learners' images (images 1.2 and 1.4). Samia looks at the resources as she needs to refer to the lesson plan when giving directions. Her gaze is directed towards learner images when she uses the learners' names (vocatives) to assign their roles.

Lines 2-4 show evidence of a side sequence that consists of a pre-emptive vocabulary check to clarify the meaning of the word manager, which is a key word for understanding the roles in the rehearsal task. Following further explanation, the trainee then addresses Sean, again using his name, to verify his understanding of the word co-worker (line 5). Sean repeats the word 
in line 6. His rising intonation and pause signal to Samia that he may not know the word, so she contextualises the word by adding at McDonald's (line 7). His filler and pause (eh:) in line 8 again makes Samia confirm that Sean may not know the word, so she switches to the written mode as a semiotic resource to facilitate meaning negotiation. Once the word appears in the visual mode, he acknowledges his recognition and marks understanding with an oh, or a changeof-state token as defined by Heritage (1984), and by repeating the word. Sean then embarks on a possible definition (lines 11-12).

Samia further supports Sean's turns by not interrupting them too quickly demonstrated by the pauses at the end of Sean's turns (lines $6,8,10,11,13$ ). In line 14, by using des she attempts to elicit the word employee or the correct use of the article les. When she elicits the word employees (line 13), she provides an explicit positive assessment (Waring, 2008) affirming Sean's understanding (line 14). Once this series of side-sequences to clarify key vocabulary is completed, between lines 14 and 15, during the pause, Samia takes a breath, directs her gaze towards the task resources on the screen (image 1.6) and, with a marker (donc) re-initiates task instructions. In other words, Samia manages a shift in focus from meaning negotiation for a vocabulary item to instructions. Her gaze back to the left-hand side of the screen that accompanies this shift to instructions manifests her need to read the task instructions in order to follow the lesson plan.

\section{Appendix 2. Conventions used in excerpts to report verbal mode}

(1.4) Numbers enclosed in parentheses indicate a pause, represented in seconds.

[utterance] Portion overlaps with a portion of another speaker's utterance

(( )) Description of an action in the verbal mode e.g. ((coughs)).

Bold $^{1}$ Portion of speaker's utterance during which the screen capture indicated by the number in superscript was taken. 
/ Rising intonation

$\backslash \quad$ Falling intonation

: $\quad$ Sound is extended

- Standard liaison

Elision

A dash indicates an abrupt cut-off where the speaker stopped speaking suddenly

CAP Capital letters indicate that the speaker spoke the capitalized portion of the utterance at a higher volume than the speaker's normal volume.

(inaud) The transcriber was not able to decipher the audio.

\section{References}

Andersen, P. A. (2008). Nonverbal communication: forms and functions. Illionis: Waveland Press Inc.

Breen, M. (1987). Contemporary paradigms in syllabus design. Language Teaching, 20(3), 158-174.

Codreanu, T., \& Combe Celik, C. (2013). Effects of webcams on multimodal interactive learning. $\operatorname{ReCALL}, 25(1), 30-47$.

Council of Europe (2001). Common European Framework of Reference for Languages: Learning, Teaching, Assessment. Cambridge: Cambridge University Press.

Develotte, C., Guichon, N., \& Vincent, C. (2010). The use of the webcam for teaching a foreign language in a desktop videoconferencing environment. ReCALL, 23(3), 293-312.

Ellis, R. (2003). Task-based language learning and teaching. New York: Oxford University Press.

Guichon, N. (2017). Se construire une présence pédagogique en ligne. In Guichon, N. \& Tellier, M. (eds.) Enseigner l'oral en ligne. Une perspective multimodale, (pp.31-58). Paris: Dider.

Guichon, N., Bétrancourt, M., \& Prié, Y. (2012). Managing written and oral negative feedback in a synchronous online teaching situation. Computer Assisted Language Learning, 25(2), 181-197.

Guichon, N., Blin, F., Wigham, C.R. \& Thouësny, S. (2014) ISMAEL LEarning and TEaching Corpus.

Dublin, Ireland: Centre for Translation and Textual Studies \& Lyon, France: Laboratoire ICAR. 
Guichon, N., \& Cohen, C. (2016). Multimodality and CALL. In Farr, F \& Murray, L. (eds.). The Routledge handbook of language learning and technology, (pp. 509-521). London: Routledge.

Guichon, N. \& Nicolaev, V. (2011). Influence de certaines caractéristiques des tâches d'apprentissage sur la production orale en L2. In Nissen, E., Poyet, F. \& Soubrié, T. (eds.). Interagir et apprendre en ligne, (pp. 61-76). Grenoble: Ellug.

Guichon, N. \& Wigham, C.R. (2016). A semiotic perspective on webconferencing-supported language teaching. ReCALL, 28(1). pp.62-82.

Hall, E. T. (1974). Handbook of proxemic research. Washington, DC: Society for the anthropology of visual communication.

Hampel, R., \& Stickler, U. (2012). The use of videoconferencing to support multimodal interaction in an online language classroom. ReCALL, 24(2), 116-137.

Hellermann, J., \& Pekarek Doehler, S. (2010). On the contingent nature of language learning tasks Classroom Discourse, 1(1), 25-45.

Heritage, J. (1984 ). A change-of-state token and aspects of its sequential placement. In J. M. Atkinson \& J. Heritage (eds), Structures of social action, (pp. 299-345). Cambridge: Cambridge University Press. Jefferson, G. (1972). Side sequences. In D. Sundow (eds.) Studies in social interaction, (pp. 294-451). New York: The Free Press.

Jewitt, C. (2011). Different approaches to multimodality. In C. Jewitt (Ed.), The Routledge handbook of multimodal analysis, (pp. 28-39). London: Routledge

Jewitt, C., Bezemer, J. J., \& O'Halloran, K. L. (2016). Introducing multimodality. London: Routledge.

Jones, R. H. (2012). Discourse analysis: A resource book for students. London: Routledge

Kääntä, L. (2015). The multimodal organisation of teacher-led classroom interacation. In P. Seedhouse and C. Jenks (eds.) International perspectives on the ELT classroom, (pp.64-83). Basingstoke: Palgrave MacMillan.

Kendon, A. (1982). The study of gesture: some observations on its history. Recherches Semiotique/Semiotic Inquiry, 2(1), 25-62.

Kendon, A. (1977). Studies in the behavior of face-to-face interaction. Lisse: Peter De Ridder Press. 
Lamy, M-N. (2009). Multimodality in second language conversations online: Looking for a methodology, In A. Baldry \& E. Montagna (eds.), Interdisciplinary perspectives on multimodality: Theory and practice, (385-403). Campobasso: Palladino.

Lamy, M-N. \& Flewitt, R. (2011). Describing online conversations: insights from a multimodal approach. In C. Develotte, R. Kern \& M-N. Lamy (eds.), Décrire la conversation en ligne: la face à face distanciel. Lyon: ENS.

Markee, N. (2013). Contexts of change. In K. Hyland and L. Wong (eds.), Innovation in English language education, (pp.173-193). Abingdon: Routledge.

Markee, N. (2015a). Giving and following pedagogical instructions in task-based instruction: An ethnomethodological perspective. In P. Seedhouse and C. Jenks (eds.) International perspectives on the ELT classroom, (pp.110-128). Basingstoke: Palgrave MacMillan.

Markee, N. (2015b). Teachers' instructions: Toward a collections-based, comparative research agenda in classroom conversation analysis. Paper presented at HUMAN Social Interaction and Applied Linguistics Postgraduate Conference, 08 September 2015, Hacettepe University, Ankara. [https://sial2015hu.files.wordpress.com/2015/09/1-ankara-paper-final.pdf]

Martin, F., Parker, M., \& Allred, B. (2013). A case study on the adoption and use of synchronous virtual classrooms. The Electronic Journal of e-Learning, 11(2), 124-138.

McNeill, D. (1992). Hand and mind: What gestures reveal about thought. Chicago, London: University of Chicago press.

Messina Dahlberg, G., \& Bagga-Gupta, S. (2015). Learning on-the-go in institutional telecollaboration: Anthropological perspectives on the boundaries of digital spaces. In E. Dixon \& M. Thomas (Eds.), Researching language learning interaction online: From social media to MOOCs, (259-281). San Marcos, TX: CALICO.

MODE (2012). Glossary of multimodal terms. https://multimodalityglossary.wordpress.com/.

Norris, S. (2004). Analyzing multimodal interaction: A methodological framework. London: Routledge.

Norris, S., \& Pirini, J. (2016). Communicating Knowledge, Getting Attention, and Negotiating

Disagreement via Video Conferencing Technology: A Multimodal Analysis. Journal of Organizational Knowledge Communication, 3(1), 23-48. 
Nunan, D. (2004). Task-Based Language Teaching. Cambridge: Cambridge University Press.

Örnberg Berglund, T. (2009). Multimodal student interaction online: An ecological perspective. ReCALL, 21(2), 186-205.

Pica, T., Kanagy, R., \& Falodun, J. (1993). Choosing and using communication tasks for second language instruction. In G. Crookes \& S. Gass (eds.), Tasks and language learning, (pp. 9-34). Clevedon: Multilingual Matters.

Raith, T., \& Hegelheimer, V. (2010). Teacher Development, TBLT and Technology. In M. Thomas \& H. Reinders (eds.), Task-based language learning and teaching with technology, (pp.154-175). London: Continuum.

Satar, H. M. (2013). Multimodal Language Learner Interactions via Desktop Videoconferencing within a Framework of Social Presence: Gaze. ReCALL, 25(1), 122-142.

Seedhouse, P. (2008). Learning to talk the talk: Conversation analysis as a tool for induction of trainee teachers. In Garton, S. \& Richards, K. (eds). Professional encounters in TESOL: Discourses of teachers in training (pp. 42-57). Basingstoke: Palgrave Macmillan.

Sert, O. (2013). Integrating digital video analysis software into language teacher education: Insights from conversation analysis. Procedia-Social and Behavioral Sciences (Proceedings of Akdeniz Language Studies Conference), 70, 231-238.

http://www.sciencedirect.com/science/article/pii/S1877042813000608

Sindoni, M. G. (2013). Spoken and written discourse in online interactions: A multimodal approach. London: Routledge.

Sloetjes, H., \& Wittenburg, P. (2008). Annotation by category - ELAN and ISO DCR. In Proceedings of the 6th International Conference on Language Resources and Evaluation (LREC 2008).

Tellier, M. (2017). Geste coverbal. Entrée glossaire. In Guichon, N. \& Tellier, M. (eds.). Enseigner l'oral en ligne. Une perspective multimodale, (pp.15). Paris: Dider.

Yen, YC., Hou, H-T., \& En Chang, E. (2015). Applying role-playing strategy to enhance learners' writing and speaking skills in EFL courses using Facebook and Skype as learning tools: A case study in Taiwan. Computer Assisted Language Learning, 28(5), 383-406. 
Van den Branden, K. (2006). Introduction: Task-based language teaching in a nutshell, In K. Van den Branden (eds). Task-Based language education: From theory to practice. Cambridge: Cambridge University Press.

Van Leeuwen, T. (2004). Introducing Social Semiotics: An Introductory Textbook. London: Routledge.

Waring, H. Z. (2008). Using Explicit Positive Assessment in the Language Classroom: IRF, Feedback, and Learning Opportunities. The Modern Language Journal, 92, 577-594.

Watson Todd, R. (1997). Classroom teaching strategies. London: Prentice Hall.

Watson Todd, R., Chaiyasuk, I., \& Tantisawatrat, N. (2008). A functional analysis of teachers' instructions. RELC Journal, 39, 25-50. 